\title{
Timotein maantieteelliset geenipoolit ja niiden käyttö jalostusohjelmissa
}

Mika Isolahti

Boreal Kasvinjalostus Oy, 31600 Jokioinen, mika.isolahti@boreal.fi

\section{Tiivistelmä}

Timotein (Phleum pratense L.) tärkeimpiä viljelyalueita ovat Skandinavia, Venäjä, Japani, KeskiEurooppa ja Pohjois-Amerikka. Timoteilla voidaan erottaa eri kasvutyyppejä maantieteellisen alkuperän mukaan. Suomessa ja muualla Skandinavian pohjoisemmissa osissa viljellyillä timoteilajikkeilla on ollut erittäin hyvä talvehtimiskyky. Niiden sato on painottunut ensimmäiseen satoon, ts. jälkikasvukyky on ollut suhteellisen vaatimaton. Perinteiset pohjoisen tyypin timoteit ovat kahden niiton lajikkeita. Eteläisempää tyyppiä edustavien lajikkeiden jälkikasvukyky on parempi ja ne voidaan niittää useampia kertoja. Talvenkestävyys ei yleensä riitä Suomen olosuhteissa.

Erilaista maantieteellistä alkuperää olevaa materiaalia käyttämällä voidaan parantaa toiselle maantieteelliselle alueelle tehtävää jalostusohjelmaa tuomalla ohjelmaan uusia ominaisuuksia. Suomessa käytettyjen timoteilajikkeiden heikkous on niiden huono jälkikasvukyky. Jälkikasvukykyä voidaan parantaa käyttämällä eteläisempää alkuperää olevaa kasvimateriaalia. Tuotaessa eteläistä materiaalia Suomeen suunnattuun jalostusohjelmaan ongelmaksi tulee talvenkestävyyden heikkeneminen sekä sadon laadun aleneminen. Talvehtimiseen liittyviä ongelmia voidaan välttää testaamalla eri maantieteellistä alkuperää oleva kasvimateriaali riittävän ankarassa valintatestissä ennen jalostusohjelmaan sisään vientiä. Eteläisempää alkuperää oleva materiaalin laatu on yleensä heikompi. Kehitysrytmi on selvästi nopeampi kuin pohjoisella materiaalilla ja korren osuus biomassasta on suurempi. Ilmeisesti myös ligniinin ja iNDF-kuidun osuus korressa on suurempi. Laatuominaisuuksista saadaan ensimmäiset luotettavat havainnot jälkeläistestauksessa, minkä jälkeen materiaalia voidaan käyttää varsinaisten synteettisten linjojen tekemiseen.

Jalostusohjelmissa voidaan tavoitella joko paikallista tai laajaa sopeutumista. Perinteisesti timoteita on jalostettu hyvinkin spesifisille kohdealueille, esimerkiksi Pohjois- ja Etelä- Suomeen on jalostettu omia lajikkeita. Kuitenkin nykyiset modernit timoteilajikkeet, joiden taustalla on laajempi geenipooli, menestyvät hyvin koko maassa. Talvehtimisessa ei ole ongelmia, jälkikasvukyky ja laatu ovat parempia kuin vanhoilla lajikkeilla.

Viime kädessä lajikemarkkinan koko ratkaisee sen miten suuri lajikkeen adaptaatiokyvyn pitää olla. Laajemmassa tarkastelussa timoteilla voidaan erottaa neljä laajempaa potentiaalista jalostuksen kohdealuetta: 1. Skandinavian pohjoisosa (Suomi, Ruotsi (keski- ja pohjoisosa), Norja, Islanti), 2. mantereinen Keski-Eurooppa, 3. merellinen Keski-Eurooppa, 4. Pohjois-Amerikka. Vaatimukset lajikkeille vaihtelevat vielä kohdealueittain ja maittain, esim. sadon määrän ja laadun merkityksen suhteen.

Kohdealuekohtaisen jalostustyön synnyttämää vaihtelua voidaan hyödyntää muille kohdealueille tehtävissä jalostusohjelmissa soveltuvin osin. Käyttämällä laajaa geneettistä pohjaa jalostuksessa on mahdollista tehdä lajikkeita joilla on erittäin laaja adaptaatiokyky.

Asiasanat: timotei, jalostus, adaptaatio, talvehtiminen, rehulaatu 


\section{Timotei rehukasvina}

Timotei eli nurmitähkiö (Phleum pratense L.) on monivuotinen löyhästi mätästävä ruoho. Timotei on Phleum-suvun lajeista ainut, jolla on taloudellista merkitystä (Berg ym. 1996). Timotei on levinnyt ihmisen toimesta kaikkialle lauhkealle ja subarktiselle vyöhykkeelle (Klebesadel ja Helm 1986, Berg ym. 1996).

Timotei on sopeutunut viileään ja kosteaan ilmastoon (Klebesadel ja Helm 1986, Berg ym. 1996), minkä vuoksi se on hyvä viljelykasvi myös Suomessa (Pulli 1980). Timotein talvenkestävyys on hyvä ja se onkin talvenkestävin Suomessa viljellyistä nurmikasveista. Tietyillä Pohjois- ja ItäSuomen runsaslumisilla alueilla timotei kärsii talvituhosienistä (Jamalainen 1974, Nissinen 1996). Timotein ravitsemuksellinen arvo nautaeläinten ruokinnassa on hyvä (Berg ym. 1996). Timoteita voidaan viljellä puhtaana kasvustona, seoksena muiden nurmikasvien tai nurmipalkokasvien, kuten punaapilan (Trifolium pratense L.) kanssa (Pulli 1980, Nissinen ja Hakkola 1995, Berg ym. 1996). Timotein kasvurytmi on alkukasvukauteen painottuva (Pulli 1980, Nissinen ja Hakkola 1995, Nissinen 1996). Timotein jälkikasvukyky ja sadontuotto myöhemmissä korjuissa on heikompi kuin monilla muilla nurmikasveilla, esimerkiksi nurminadalla (Festuca pratensis), ruokonadalla (Festuca arundinacea) ja koiranheinällä (Dactylis glomerata L.). Timotein juuristo on suhteellisen matala ja se on arka kuivuudelle (Berg ym. 1996, Nissinen 1996). Timotei ei kestä useita korjuukertoja, vaan se on parhaimmillaan kahden korjuukerran viljelyjärjestelmissä (Pulli 1980, Nissinen ja Hakkola 1995).

\section{Timotein kasvutyypit ja viljelyalueet}

Timotein tärkeimpiä viljelyalueita ovat Skandinavia, Venäjä, Japani, Keski-Eurooppa ja PohjoisAmerikka. Timoteilla voidaan erottaa useita eri kasvutyyppejä niiden maantieteellisen alkuperän mukaan.

Suomessa ja muualla Skandinavian pohjoisemmissa osissa tyypillisesti viljellyillä timoteilajikkeilla on ollut erittäin hyvä talvehtimiskyky. Käytettyjen lajikkeiden sato on painottunut ensimmäiseen satoon ja vastaavasti jälkikasvukyky on ollut suhteellisen vaatimaton. Perinteiset pohjoisen tyypin timoteit ovatkin puhtaita kahden niiton lajikkeita. Äärimmäisenä esimerkkinä pohjoisen tyypin lajikkeesta voidaan pitää Norjalaista Engmo-lajiketta, joka on jalostettu 68 leveyspiirin pohjoispuolelta kerätyistä timoteiyksilöistä. Lajike on erittäin hyvä talvehtimiskyvyltään, mutta sen jälkikasvukyky on vastaavasti erittäin heikko. Iki on kotimainen lajike, joka edustaa Pohjois-Suomen olosuhteisiin hyvin soveltuvaa talvenkestävää perinteisen tyypin lajiketta. Iki on risteytetty Sodankylän, Tervolan, Posion ja Pelson alueelta kerätyistä valioyksilöistä. Ikilläkin jälkikasvukyky on heikko.

Eteläisempää tyyppiä edustavien lajikkeiden jälkikasvukyky on selvästi parempi kuin pohjoista tyyppiä edustavien lajikkeiden ja ne voidaan niittää useampia kertoja. Eteläisen tyypin lajikkeet ovat myös kasvurytmiltään huomattavasti nopeampia kuin pohjoista tyyppiä olevat lajikkeet. Eteläisen tyypin lajikkeiden tähkälle tulo tapahtuu Suomessa enimmillään muutamaa päivää aikaisemmin kuin pohjoisen tyypin lajikkeiden, mutta Keski-Euroopassa ja Pohjois-Amerikassa suurten järvien alueella ero tähkälle tulossa voi olla jopa yli kaksi viikkoa. Keski-Euroopassa lajikkeet jaotellaan aikaisiin, keski-aikaisiin ja myöhäisiin. Tyypillisesti Suomessa käytetyt lajikkeet ovat em. luokittelussa myöhäisiä.

Selvästi eteläistä tyyppiä olevien lajikkeiden talvenkestävyys on huomattavasti heikompi kuin pohjoisen tyypin lajikkeilla eikä yleensä riitä Suomen olosuhteissa. Talvenkestävyyden erot tulevat esiin III- ja IV-viljelyvyöhykkeillä, joilla pääosa Suomen nurmialasta sijaitsee.

Keskieurooppalaiset timoteilajikkeet voidaan jakaa edelleen mantereisiin ja merellisiin tyyppeihin. Pohjois-Amerikassa timotein pääasiallinen viljelyalue sijaitsee suurten järvien ympärillä. Pohjoisamerikkalaiset lajikkeet muistuttavat huomattavasti keskieurooppalaisia, niille on kuitenkin tyypillistä erittäin nopea karaistuminen syksyllä. 


\section{Alkuperän merkitys laatuun}

Eteläisempää alkuperää olevan timoteimateriaalin laatu on rehuarvojen perusteella useimmiten heikompi kuin pohjoisen materiaalin. Osittain heikompi laatu selittyy erilaisella kehitysrytmillä. Eteläisempien tyyppien kehitysrytmi on selvästi nopeampi kuin pohjoisen tyyppien ja myös korren osuus biomassasta on suurempi. Erilainen kehitysrytmi ei kuitenkaan selitä kaikkea vaihtelua, mitä esimerkiksi jalostajankokeissa on havaittu. Ilmeisesti ligniinin ja iNDF-kuidun osuus nimenomaan korressa on eteläisillä lajikkeilla suurempi kuin Pohjois-Skandinaviasta peräisin olevilla lajikkeilla.

\section{Uusien geenipoolien hyödyntäminen jalostusohjelmassa}

Erilaista maantieteellistä alkuperää olevaa materiaalia käyttämällä voidaan parantaa toiselle maantieteelliselle alueelle tehtävää jalostusohjelmaa tuomalla jo olemassa olevaan ohjelmaan haluttuja uusia ominaisuuksia.

Suomessa perinteisesti käytettyjen timoteilajikkeiden suurin puute on liittynyt niiden heikkoon jälkikasvukykyyn. Pohjoisen timotein jälkikasvukykyä voidaan selvästi parantaa käyttämällä eteläisempää alkuperää olevaa kasvimateriaalia. Tuotaessa eteläistä materiaalia Suomeen suunnattuun jalostusohjelmaan ongelmaksi tulee kuitenkin talvenkestävyyden heikkeneminen, sekä sadon laadun aleneminen.

Talvehtimiseen liittyviä ongelmia voidaan välttää testaamalla eri maantieteellistä alkuperää oleva kasvimateriaali riittävän ankarassa valintatestissä ennen jalostusohjelmaan sisään vientiä. Käytännössä talvehtimiskykyä on testattu paksun lumipeitteen alueella sijaitsevilla kokeilla. Vaikka ao. olosuhteissa talvituhot aiheutuvatkin etupäässä talvituhosienistä, voidaan tulokset kuitenkin yleistää koskemaan ainakin karkeasti myös abioottisia stressejä. Esimerkiksi kylmyydenkeston ja talvituhosienten kestävyyden on havaittu korreloivan keskenään timoteilla (Årsvoll 1977, Årsvoll ja Larsen 1977), nurminadalla (Årsvoll 1977, Årsvoll ja Larsen 1977) ja ruokohelvellä (Tronsmo 1983). Käytännössä ei abioottisten stressitekijöiden, kuten jääpoltteen, testaaminen luotettavasti laajoilla aineistoilla ole mahdollista.

Keskeinen tekijä talvehtimiskyvyssä on karaistumisen nopeus ja syvyys syksyllä. Karaistuneet kasvilajit ja -lajikkeet kestävät hyvin useampia eri stressitekijöitä. Eri alkuperää olevien timoteilajikkeiden ja -linjojen välillä onkin selviä eroja karaistumiskyvyssä. Eteläisellä tyypillä karaistuminen alkaa liian myöhään kasvukaudella ja kasvit altistuvat eri stressitekijöille talven aikana.

Testaamalla riittävän suuria määriä eteläistä alkuperää olevaa kasvimateriaalia voidaan löytää yksilöitä, joiden talvenkestävyys ja kasvukyky ovat fenotyyppiin perustuvassa arvioinnissa riittävän hyviä. Pidemmällä aikavälillä tavoitteena on kehittää merkkiavusteista valintaa talvenkestävyyteen ja välttää ajallisesti pitkä sekä kustannuksiltaan korkea fenotyyppivalinta.

Valittujen yksilöiden sadontuotto- ja talvehtimiskyky arvioidaan lopullisesti testiristeytyksiä seuraavien jälkeläistestien perusteella. Vastaavasti pohjoista alkuperää olevan kasvimateriaalin sadontuottokykyä voidaan arvioida jälkeläistesteillä tekemällä testit eteläisemmällä kohdealueella.

Laatuominaisuuksista saadaan ensimmäiset luotettavat havainnot jälkeläistestauksessa. Myös laatuominaisuuksien osalta merkkiavusteisen valinnan oletetaan mahdollistavan tulevaisuudessa kasvimateriaalin karsinnan jo jalostusprosessin aikaisemmassa vaiheessa.

Jälkeläistestauksella talvehtimiskyvystä, sadontuottokyvystä ja ruokinnallisesta laadusta saatujen tietojen perusteella parhaita klooneja voidaan käyttää varsinaisten synteettisten linjojen tekemiseen kullekin kohdealueelle. Lopullisesti parhaat synteettiset linjat valitaan eri kohdealueilla tehtävien finaalikokeiden sekä siementuotantokokeiden tulosten perusteella.

Testaamalla eri maantieteellistä alkuperää olevia kasvimateriaalia poikkeavassa ympäristössä voidaan löytää kasviyksilöitä joilla saadaan selvästi parannettua toisessa ohjelmassa olevaa materiaalia. Pohjoista alkuperää olevalla materiaalilla voidaan parantaa eteläisen materiaalin talvenkestävyyttä ja rehulaatuun liittyviä ominaisuuksia. Eteläisen materiaalin käytön suurin hyöty pohjoisessa materiaalissa saadaan jälkikasvukyvyn ja sadon määrän paranemisen kautta. Eri poolien käyttäminen varmistaa riittävän laajan geneettisen muuntelun jalostusohjelmien pohjaksi. 


\section{Adaptaation laajuus jalostustavoitteena}

Jalostusohjelmissa voidaan tavoitella joko paikallista tai laajaa sopeutumista. Perinteisesti timoteita on jalostettu hyvinkin spesifisille kohdealueille, esimerkiksi Pohjois- ja Etelä- Suomeen on jalostettu omia lajikkeita. Liiketaloudellisessa mielessä pienelle kohdealueelle tehtävät jalostusohjelmat eivät ole kannattavia. Jalostuksen kohdealueella täytyy olla riittävän suuri siemenmarkkina. Esimerkiksi viimevuosina Suomen markkinoille tuodut uudet modernit timoteilajikkeet, joiden taustalla on laajempi geenipooli, menestyvät hyvin koko maassa. Talvehtimisessa ei ole ongelmia, jälkikasvukyky ja laatu ovat parempia kuin vanhoilla lajikkeilla.

Viime kädessä lajikemarkkinan koko ratkaisee sen miten suuri lajikkeen adaptaatiokyvyn pitää olla. Laajemmassa tarkastelussa timoteilla voidaan erottaa neljä laajempaa potentiaalista jalostuksen kohdealuetta: 1. Skandinavian pohjoisosa (Suomi, Ruotsi (keski- ja pohjoisosa), Norja, Islanti), 2. mantereinen Keski-Eurooppa, 3. merellinen Keski-Eurooppa, 4. Pohjois-Amerikka. Vaatimukset lajikkeille vaihtelevat kohdealueilla vielä maittain, esimerkiksi sadon määrän ja laadun merkityksessä on suuria eroja.

Kohdealuekohtaisen jalostustyön synnyttämää vaihtelua voidaan hyödyntää muille kohdealueille tehtävissä jalostusohjelmissa soveltuvin osin. Käyttämällä laajaa geneettistä pohjaa jalostuksessa on mahdollista tehdä lajikkeita joilla on erittäin laaja adaptaatiokyky. Parhaimmat timoteilinjat ovatkin menestyneet hyvin useilla eri maantieteellisillä kohdealueilla.

\section{Kirjallisuus}

Berg, C.C., McElroy, A.R. \& Kunelius, H.T. 1996. Timothy. Cool-Season Forage Grasses, Agronomy Monograph no. 34: 643-664.

Jamalainen, E.A. 1974. Resistance in winter cerals and grasses to low-temperature parasitic fungi. Annual Review of Phytopathology 12: 281-302.

Klebesadel, J.L. \& Helm, D. 1986. Food reserve storage, low-temperature injury, winter survival and forage yields of timothy in subartic Alaska as related to latitude of origin. Crop Science 26: 325-334.

Nissinen, O. \& Hakkola, H. 1995. Effects of plant species and harvesting system on grassland production in northern Finland. Agricultural Science in Finland 4: 479-494.

Nissinen, O. 1996. Analyses of climatic factors affecting snow mould injury in first-year timothy (Phleum pratence L.) with special reference to Sclerotinia borealis. Acta Universitatis Oulensis. Scientiae Rerum Naturalium, A 289.

Pulli, S. 1980. Development and productivity of timothy (Phleum pratense L.). Journal of the Scientific Agricultural Society of Finland 52: 368-392.

Tronsmo, A.M. 1983. Induced resistance to biotic stress factors in grasses by frost hardening. Plant production in the North. Proceedings from Plant Adaptation Workshop, Tromso, Norway, s. 127 - 133.

Årsvoll, K. 1977. Effects of hardening plant age and development in Phleum pratense and Festuca pratensis on resistance to snow mould fungi. Scientific reports of the argricultural university of Norway. Vol 56, no. 28.

Årsvoll, K. \& Larsen, A. 1977. Effects of nitrogen, phosphorus and potassium on resistance to snow mould fungi and on freezing tolerance in Phleum pratense. Scientific reports of the argricultural university of Norway. Vol 56, no. 29. 